\title{
XRD investigation of cement pastes incorporating concrete floor polishing waste
}

\section{(Investigação por DRX de pastas de cimento com incorporação de resíduo de polimento de pisos de concreto)}

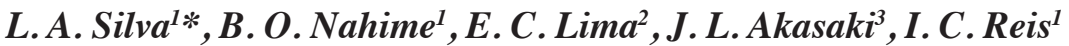 \\ ${ }^{1}$ Instituto Federal de Educação, Ciência e Tecnologia Goiano, 75901-970, Rio Verde, GO, Brazil \\ ${ }^{2}$ Universidade Federal do Tocantins, Porto Nacional, TO, Brazil \\ ${ }^{3}$ Universidade Estadual Paulista, Faculdade de Engenharia, Grupo de Pesquisa em Materiais Alternativos de \\ Construção, Ilha Solteira, SP, Brazil
}

\begin{abstract}
The X-ray diffraction (XRD) technique has been widely used in order to investigate anhydrous and hydrated cement phases. In this study, XRD was used in order to analyze the concrete floor polishing waste (CFPW) and cementitious paste containing CFPW. The diffractograms obtained were compared with literature data in order to identify the phases of analyzed materials. Rietveld refinement of XRD pattern of paste containing $12 \%$ of CFPW addition was also carried out, in order to analyze calcite and aragonite structures, as these phases are calcium carbonate polymorphs that contribute to matrix filling. XRD pattern of CFPW showed a high concentration of carbonate phases, indicating that the concrete waste was carbonated. The CFPW addition in the cementitious matrix changed the hydrate cement products, as it induced the formation of carboaluminate phases, such as hemicarbonate. Calcite, which is a stable phase, contributed better to the filler effect, as its particles have higher volume than aragonite.
\end{abstract}

Keywords: cementitious hardened paste waste, XRD qualitative analysis, Rietveld refinement.

\section{Resumo}

A técnica de difração de raios $X(D R X)$ tem sido amplamente empregada para análise das fases anidras e hidratadas do cimento Portland. Neste estudo, a técnica de DRX foi empregada para análise do resíduo de polimento de pisos de concreto (RPPC) e de pasta cimentícia com adição de RPPC. Os padrões de DRX obtidos foram comparados com dados da literatura para identificação das fases dos materiais analisados. O refinamento Rietveld do padrão de DRX da pasta com adição de $12 \%$ de RPPC foi realizado como objetivo de analisar as estruturas das fases calcita e aragonita, as quais são polimorfos do carbonato de cálcio que contribuem para o empacotamento de matrizes cimentícias. O padrão de difração do RPPC indicou elevada concentração de carbonatos, indicando a carbonatação do resíduo. A adição de RPPC em matriz cimentícia modificou os produtos de hidratação do cimento, uma vez que o resíduo induziu a formação de carboaluminatos, como o hemicarbonato. A calcita, que é uma fase estável, contribuiu melhor para o efeito de preenchimento, pois suas partículas têm maior volume que a aragonita.

Palavras-chave: resíduo de pastas cimentícias, análise qualitativa por DRX, refinamento Rietveld.

\section{INTRODUCTION}

$\mathrm{X}$-ray diffraction $(\mathrm{XRD})$ technique has been used in several works to characterize cementitious materials. XRD pattern allows the study of cement hydration products at different curing ages and with different materials additions by analyzing peak positions and relative pattern intensities [1-3]. Quantitative phase analysis (QPA) can also be carried out in order to determine the (hydrated) cement phases' concentration, as peak intensity is related to weight fraction [4]. Gray Portland cement contain alite $\left(\mathrm{C}_{3} \mathrm{~S}-3 \mathrm{CaO} \cdot \mathrm{SiO}_{2}\right)$, belite $\left(\mathrm{C}_{2} \mathrm{~S}-2 \mathrm{CaO} \cdot \mathrm{SiO}_{2}\right)$, aluminate $\left(\mathrm{C}_{3} \mathrm{~A}-3 \mathrm{CaO} \cdot \mathrm{Al}_{2} \mathrm{O}_{3}\right)$, and ferrite $\left(\mathrm{C}_{4} \mathrm{AF}-4 \mathrm{CaO} \cdot \mathrm{Al}_{2} \mathrm{O}_{3} \cdot \mathrm{Fe}_{2} \mathrm{O}_{3}\right)$ as major phases.

*araujolorena.s@gmail.com

Dhttps://orcid.org/0000-0002-8159-7472
Silicate phases, which significantly contribute to the cement matrix strength at hardened state [5], have polymorphism as a function of temperature stabilization. Alite has 7 polymorphs [6], and belite has 5 polymorphs [7]. On the other hand, pure aluminate does not exhibit polymorphism, although composition variation leads to structure variation [8]. The main product of hydrated Portland cement paste is calcium silicate hydrate (C-S-H), which is formed due to alite and belite reactions with water. This component exhibits amorphous or low crystallinity characteristics. $\mathrm{C}_{3} \mathrm{~S}$ and $\mathrm{C}_{2} \mathrm{~S}$ hydration reactions also produce calcium hydroxide (portlandite), which is crystalline and is the second main product of the hydrated paste. Ettringite and monosulphate phases are products of aluminate and ferrite hydrations, and their concentrations are due to the hydration degree of paste and aluminate and ferrite quantity [9]. When exposed to 
atmospheric conditions, $\mathrm{CO}_{2}$ diffuses through the paste and reacts with portlandite, forming calcium carbonate $\left(\mathrm{CaCO}_{3}\right)$. In this case, calcite, vaterite, and aragonite, which are $\mathrm{CaCO}_{3}$ polymorphs, can also be found in the hardened paste [10].

Rietveld method has been applied in order to study quantitative characteristics of Portland cement and hydrated Portland cement paste phases $[11,12]$. In this method, each data point of an experimental diffractogram is compared to a calculated pattern using a least-square refinement. During the refinement process, parameters such as background, scale factor, structure factor, peak profile, cell parameter, displacement, and preferential orientation are analyzed. XRD technique and Rietveld refinement are important tools for studies related to the waste used in cementitious matrices [4]. Calligaris et al. [13] characterized sugar cane straw ash (SCSA) and quantified hydrated phases in cements incorporating SCSA using XRD results and Rietveld analysis. Chen and Poon [14] also used these techniques in order to study phase formation in mortars containing sewage sludge ash and fly ash. The search for waste uses in cement matrices is related to the environmental need to finding solutions that mitigate the environmental impacts generated by the different economic sectors. Civil construction generates a high amount of waste during its construction, reform, and demolition activities [15], citing, as an example, the concrete floor polishing process. Concrete floors are solutions commonly used in malls, airports, and sheds, as they present great performance when exposed to traffic loads. In the finishing process, the floor is polished in order to obtain a better material aesthetic quality. This process generates sludge waste, which is commonly discarded. Considering the economic and environmental impacts associated with the transport and waste disposal, solutions that propose its use in new materials production are relevant in the current context of sustainable development.

In this context, this work aims to study the use of the XRD technique to investigate cement pastes incorporating concrete floor polishing waste (CFPW). For this purpose, samples of control paste and paste with $12 \%$ of CFPW addition were analyzed in an XRD instrument. The diffractograms obtained were compared to literature patterns, and the data obtained were refined using the Rietveld method, in order to obtain qualitative information of the samples studied.

\section{MATERIAL AND METHODS}

The concrete floor polishing waste (CFPW) was collected during the polishing process of a shed concrete floor, which was under construction in Rio Verde city (Goiás), Brazil. The microconcrete used in the floor construction was
Table II - Mixture proportions of pastes.

[Tabela II - Proporção das misturas das pastas.]

\begin{tabular}{ccc}
\hline Component & Control & $12 \%$ CFPW \\
\hline PC - type III* $(\mathrm{g})$ & 500 & 500 \\
CFPW $(\mathrm{g})$ & - & 60 \\
Water $(\mathrm{g})$ & 170 & 170 \\
$\mathrm{w} / \mathrm{c}$ & 0.34 & 0.34 \\
\hline * specific gravity: $3.07 \mathrm{~g}^{\mathrm{cm}} \mathrm{cm}^{3} \cdot$ w/c water/cement mass ratio &
\end{tabular}

* specific gravity: $3.07 \mathrm{~g} / \mathrm{cm}^{3} ; \mathrm{w} / \mathrm{c}$ : water/cement mass ratio.

produced by the mechanical mixture of high early strength Portland cement (type III) and natural aggregates (2.36 to $4.75 \mathrm{~mm}$ ) with a 1:2:0.42 cement-aggregate-water ratio. In the polishing process, a machine with diamond abrasive grits promoted the floor refinement. Water was used in order to avoid the suspension of produced powder. Therefore, a sludge waste composed of hardened cementitious paste and water was generated. This material was collected and stored in closed containers at room temperature. The sludge was dried in a laboratory oven at $65{ }^{\circ} \mathrm{C}$ until mass constancy. After drying, the sludge turned into a fine powder, which was milled in a dispersion mixer in order to standardize the material granulometry and disaggregate clods. Before experimental tests, CFPW was sieved in a 150 mesh sieve and stored in closed containers to avoid contamination.

The specific surface (Blaine method) and specific gravity (Le Chatelier method) of CFPW used in the paste production were $1031.6 \mathrm{~m}^{2} / \mathrm{kg}$ and $2.14 \mathrm{~g} / \mathrm{cm}^{3}$, respectively. X-ray fluorescence technique (XRF) was used to characterize CFPW powder. The test was performed using a WDS Bruker S8 Tiger spectrometer. The sample was first dried at $105^{\circ} \mathrm{C}$ for $12 \mathrm{~h}$. To determine the loss on ignition (LOI), the sample was calcined at $1000{ }^{\circ} \mathrm{C}$ for $5 \mathrm{~h}$. Table I shows the oxide percentages and LOI of CFPW. Calcium oxide was the main component present in the sample $(41 \%)$. Low percentages of $\mathrm{SiO}_{2}(10.3 \%)$ and $\mathrm{MgO}(8.3 \%)$ were also observed. High LOI value (36.0\%) indicated a high percentage of carbonate content in the sample.

In order to study the CFPW addition influence in cementitious matrices, control paste and paste with $12 \%$ of CFPW addition were produced and tested using X-ray diffraction (XRD) technique. The mixture proportions of pastes are presented in Table II, which were produced in accordance with ASTM C 150 standard [16]. Tablet specimens (diameter: $10 \mathrm{~mm}$; thickness: $4 \mathrm{~mm}$ ) of pastes were molded. After $24 \mathrm{~h}$ of molding, the samples were demolded and kept submerged in water for 28 days. For XRD analysis, the samples were immersed in acetone and dried at $65^{\circ} \mathrm{C}$ in a laboratory oven for $30 \mathrm{~min}$ in order to stop the cement hydration. The tablets were stored in vacuum

Table I - Chemical composition of CFPW.

[Tabela I - Composição química do RPPC.]

\begin{tabular}{ccccccccccccc}
\hline $\mathrm{SiO}_{2}$ & $\mathrm{TiO}_{2}$ & $\mathrm{Al}_{2} \mathrm{O}_{3}$ & $\mathrm{Fe}_{2} \mathrm{O}_{3}$ & $\mathrm{MnO}$ & $\mathrm{MgO}$ & $\mathrm{CaO}$ & $\mathrm{Na}_{2} \mathrm{O}$ & $\mathrm{K}_{2} \mathrm{O}$ & $\mathrm{P}_{2} \mathrm{O}_{5}$ & $\mathrm{SO}_{3}$ & LOI & Total \\
\hline 10.3 & 0.1 & 1.8 & 1.3 & $<\mathrm{QL}$ & 8.1 & 41.0 & $<\mathrm{QL}$ & 0.2 & $<\mathrm{QL}$ & 1.2 & 36.0 & 100.0 \\
\hline
\end{tabular}

QL: quantifiable limit; LOI: loss on ignition. 
Table III - Structural models of the phases used in Rietveld refinement. [Tabela III - Modelos estruturais das fases utilizadas no refinamento Rietveld.]

\begin{tabular}{cccc}
\hline Phase & Chemical formula & Crystal system notation & ICSD code \\
\hline Alite & $3 \mathrm{CaO} \cdot \mathrm{SiO}_{2}$ & Monoclinic / $\mathrm{M}_{3}$ & 94742 \\
Belite & $2 \mathrm{CaO} \cdot \mathrm{SiO}_{2}$ & Monoclinic / $\beta$ & 79550 \\
Portlandite & $\mathrm{Ca}(\mathrm{OH})_{2}$ & Rhombohedral & 15471 \\
Ettringite & $\mathrm{Ca}_{6} \mathrm{Al}_{2}\left(\mathrm{SO}_{4}\right)_{3}(\mathrm{OH})_{12} \cdot 26 \mathrm{H}_{2} \mathrm{O}$ & Rhombohedral & 155395 \\
Monosulfoaluminate & $\mathrm{Ca}_{4} \mathrm{Al}_{2}(\mathrm{OH})_{12} \mathrm{SO}_{4} \cdot 6 \mathrm{H}_{2} \mathrm{O}$ & Rhombohedral & 24461 \\
Tobermorite & $\mathrm{Ca}_{5} \mathrm{Si}_{6} \mathrm{O}_{16}(\mathrm{OH})_{2} \cdot 7 \mathrm{H}_{2} \mathrm{O}$ & Monoclinic & 152489 \\
Calcite & $\mathrm{CaCO}_{3}$ & Rhombohedral & 79673 \\
Vaterite & $\mathrm{CaCO}_{3}$ & Monoclinic & 424575 \\
\hline
\end{tabular}

Table IV - Mortar mixture proportions.

[Tabela IV - Proporções das misturas de argamassa.]

\begin{tabular}{ccc}
\hline Component & Control & $12 \%$ CFPW \\
\hline PC - type III* $(\mathrm{g})$ & 625 & 625 \\
CFPW $(\mathrm{g})$ & - & 75 \\
Sand $(\mathrm{g})$ & 1875 & 1875 \\
Water $(\mathrm{g})$ & 388 & 388 \\
w/c & 0.62 & 0.62 \\
\hline
\end{tabular}

* specific gravity: $3.07 \mathrm{~g} / \mathrm{cm}^{3} ; w / c$ : water/cement mass ratio.

plastic bags until the test day.

XRD patterns of raw materials (cement and CFPW) and pastes were obtained using a Rigaku Ultima IV diffractometer with $\mathrm{CuK} \alpha(1.5406 \AA)$ monochromatic radiation. XRD measurements were taken at room temperature in step-scan mode using Bragg-Brentano geometry and scanning the $2 \theta$ angle from $20^{\circ}$ to $60^{\circ}$ in order to carry out qualitative analyzes of the raw materials and pastes. Rietveld refinement was performed with the experimental data of paste with $12 \%$ of CFPW addition using GSAS software [17]. Peak profiles were fitted using the Thompson-Cox-Hastings pseudo-Voigt function [18], while a shifted Chebyshev polynomial with 6 terms was used to fit the background. The main criteria for judging the fitting quality as the final fit of calculated pattern compared to the observed data are the R-factors, the weighted profile $\mathrm{R}_{\mathrm{wp}}$, the statistically expected $\mathrm{R}_{\text {exp }}$, and the goodness of fit index $\chi^{2}=R_{\text {wp }} / R_{\exp }$ [19], which are usually used to attest the fit of the structural model quality of the main phases obtained from the ICSD database. The phases used in the Rietveld refinement of the XRD pattern of paste are presented in Table III.

A mechanical compression test was also performed to evaluate the influence of CFPW addition in mortars. Mixture proportions are presented in Table IV, which were prepared in a mechanical mixer ( $30 \mathrm{~s}$ low speed, $15 \mathrm{~s}$ resting, $60 \mathrm{~s}$ high speed). Six specimens of each trace were molded and kept submerged in water until test day (28 days of curing). The surface of the samples was regularized using a concrete grinder and tested in a hydraulic press (Instron Emic 23300 ) operating in a stress rate of $0.25 \mathrm{MPa} / \mathrm{s}$.

\section{RESULTS AND DISCUSSION}

XRD patterns of Portland cement and CFPW: the XRD pattern of Portland cement type III is shown in Fig. 1a. The diffraction angle and d-spacing values of most intense peaks of the cement pattern are presented in Table V, which were used in order to identify the main phases. The Portland cement

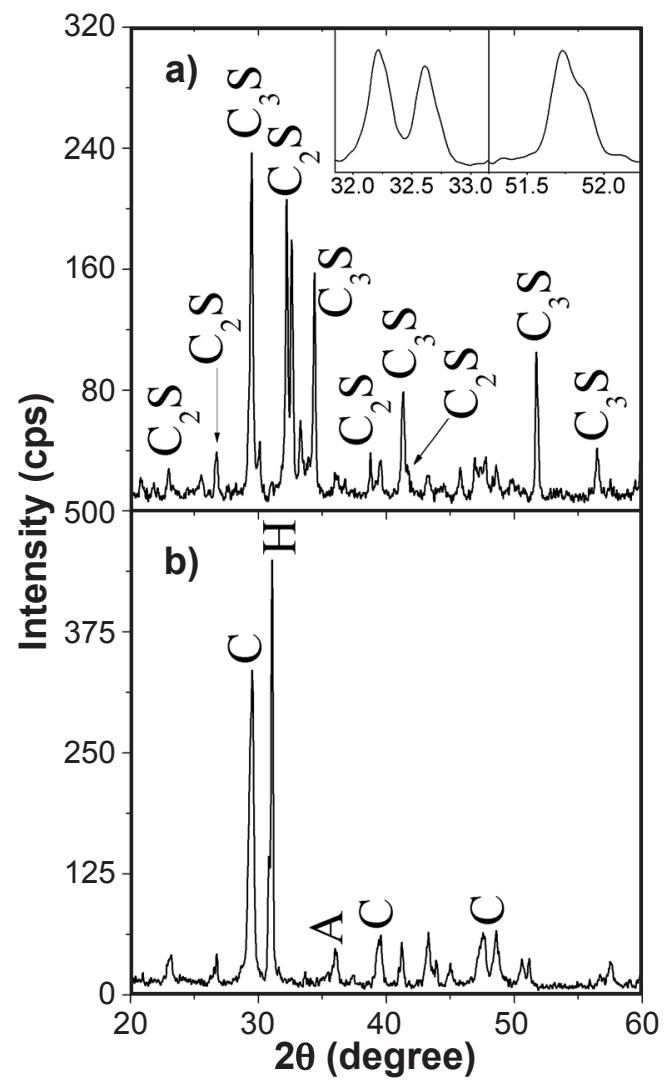

Figure 1: XRD patterns of: a) Portland cement; and b) concrete floor polishing waste (CFPW). Crystalline phases identification: $\mathrm{C}_{2} \mathrm{~S}$ : di-calcium silicate (belite); $\mathrm{C}_{3} \mathrm{~S}$ : tri-calcium silicate (alite); $\mathrm{C}$ : calcite; A: aragonite; $\mathrm{H}$ : hemicarbonate.

[Figura 1: Padrões de DRX do: a) cimento Portland; e b) resíduo de polimento de pisos de concreto (RPPC). Identificação das fases cristalinas: $\mathrm{C}_{2} \mathrm{~S}$ : silicato dicálcico (belita); $\mathrm{C}_{3} S$ : silicato tricálcico (alita); C: calcita; A: aragonita; H: hemicarbonato.] 
Table V - Structural information of Portland cement (type III) and CFPW phases.

[Tabela V - Informações estruturais das fases do cimento Portland (tipo III) e do RPPC.]

\begin{tabular}{ccc}
\hline $2 \theta$ & d-spacing $(\AA)$ & Phase \\
\hline $3.0^{\circ}$ & Portland cement (type III) & \\
$29.5^{\circ}$ & 3.06 & Belite $\gamma$ \\
$32.2^{\circ}$ & 2.78 & Alite M \\
$32.6^{\circ}$ & 2.74 & Alite M \\
$33.3^{\circ}$ & 2.69 & Alite M \\
$34.4^{\circ}$ & 2.60 & Aluminate/ferrite \\
$38.8^{\circ}$ & 2.32 & Alite \\
$41.3^{\circ}$ & 2.18 & Belite $\alpha_{\mathrm{L}}$ \\
$51.7^{\circ}$ & 1.77 & Alite M \\
& CFPW & \\
$26.7^{\circ}$ & 3.33 & Clite M \\
$29.5^{\circ}$ & 3.03 & Calcite \\
$31.1^{\circ}$ & 2.88 & Hemicarbonate \\
$36.0^{\circ}$ & 2.49 & Aragonite \\
$39.6^{\circ}$ & 2.28 & Calcite \\
$47.6^{\circ}$ & 1.91 & Calcite \\
$48.6^{\circ}$ & 1.87 & Calcite \\
\hline
\end{tabular}

powder studied (type III) contained alite, belite, aluminate, and ferrite as major crystalline phases, which corresponded to the main components of the clinker. The main peaks of $\mathrm{C}_{3} \mathrm{~S}$ were found at $29.5^{\circ}, 32.2^{\circ}, 32.6^{\circ}, 34.4^{\circ}, 41.3^{\circ}$, and $51.7^{\circ}$; and $\mathrm{C}_{2} \mathrm{~S}$ were found at $23.0^{\circ}$ and $38.8^{\circ}$. It is known that alite has 7 polymorphs as a function of temperature stabilization: 3 triclinic $\left(\mathrm{T}_{1}, \mathrm{~T}_{2}\right.$, and $\left.\mathrm{T}_{3}\right), 3$ monoclinic $\left(\mathrm{M}_{1}\right.$, $\mathrm{M}_{2}, \mathrm{M}_{3}$ ) and one rhombohedral (R). In the cement industry, the most common alite polymorphs in clinkers are $\mathrm{M}_{1}$ and $\mathrm{M}_{3}$ [20]. The peaks at the range of $32.0^{\circ}$ to $33.0^{\circ}$ and $51.5^{\circ}$ to $52.0^{\circ}$ showed in the inset of Fig. 1a indicated the presence of alite $M_{3}$ polymorph in the cement studied [21, 22], which contributed less to the compressive strength after cement hydration when compared to $\mathrm{M}_{3}$ polymorph [23].

XRD pattern of CFPW (Fig. 1b) showed that the main waste component was calcium carbonate, in accordance with the chemical composition, as summarized in Table V. This indicated that the cured paste was carbonated during the waste process of collection, transportation, and storage. Therefore, two calcium carbonate polymorphs were observed, calcite and aragonite; Table $\mathrm{V}$ shows the diffraction angles and d-spacing values of the main peaks presented in CFPW pattern. The carbonation process occurs mainly due to the reaction of calcium hydroxide $\left[\mathrm{Ca}(\mathrm{OH})_{2}\right]$ with carbon dioxide, resulting in calcium carbonate precipitation, which decreases the cementitious matrix porosity. Calcite is the most stable polymorph of calcium carbonate at ordinary temperature and pressure; aragonite and vaterite, which are two crystalline polymorphs of $\mathrm{CaCO}_{3}$, are metastable phases that finally converts into calcite [24, 25]. In the CFPW sample studied, calcite polymorph was predominant, indicating that the carbonation process was advanced and that the metastable phases were already converted into calcite. Although vaterite is the polymorph that has higher volume and thus promotes better filler effect in cementitious pores [26], calcite also contributes to improving strength and durability of cement pastes [25]. The main calcite peaks were found at $29.5^{\circ}, 39.6^{\circ}, 47.6^{\circ}$, and $48.6^{\circ}$ in accordance with [4], and aragonite was found at $36.0^{\circ}$ in accordance with [27]. Besides these crystalline phases, hemicarbonate $\left(2 \theta=31 \cdot 1^{\circ}\right)$ was also observed [4]. After the reaction of $\mathrm{C}_{3} \mathrm{~A}$ and $\mathrm{C}_{4} \mathrm{AF}$ with gypsum and formation of ettringite in the cement paste, the remaining aluminates reacted with calcium carbonate forming the hemicarbonate phase [28].

XRD patterns and compressive strength of control paste and paste with $12 \%$ of CFPW: the XRD patterns of control paste and paste incorporating $12 \%$ of CFPW are shown in Figs. $2 a$ and $2 b$, respectively. The diffraction angles and d-spacing values of the sample's main phases are shown in Table VI. It can be observed that the diffractogram

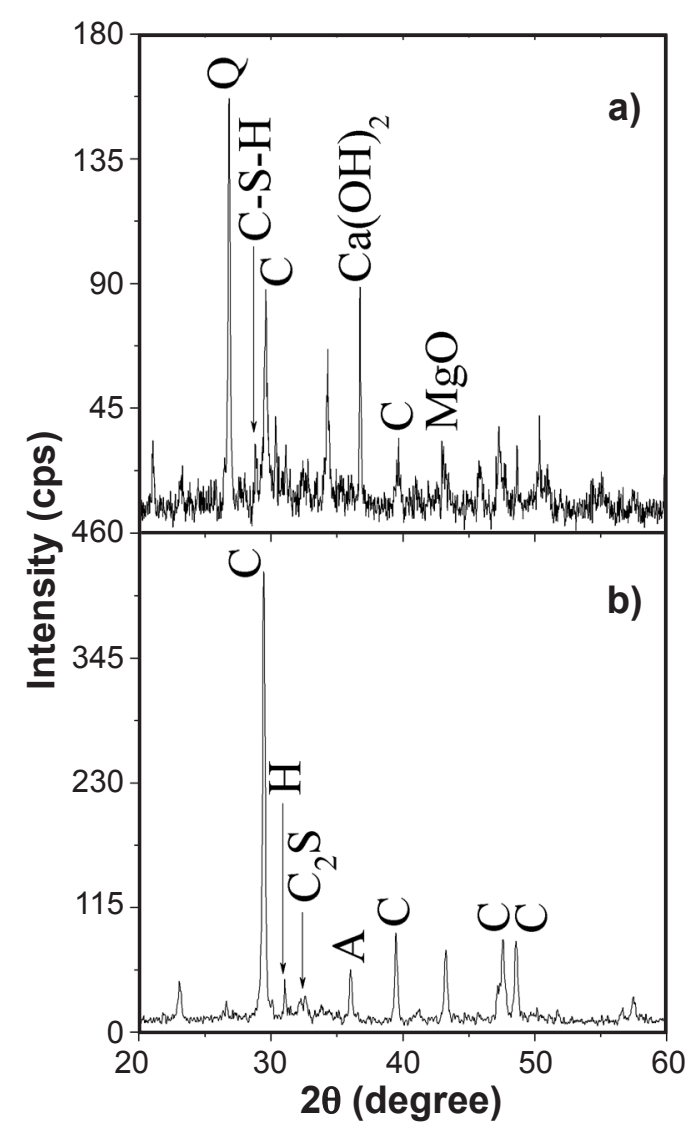

Figure 2: XRD patterns of: a) control paste; and b) paste with $12 \%$ of CFPW.Q: quartz; C-S-H: tobermorite; $\mathrm{C}$ : calcite; $\mathrm{Ca}(\mathrm{OH})_{2}$ : portlandite; $\mathrm{MgO}$ : periclase; $\mathrm{H}$ : hemicarbonate; $\mathrm{C}_{2} \mathrm{~S}$ : belite; A: aragonite.

[Figura 2: Padrões de DRX da: a) pasta de controle; e b) pasta com $12 \%$ de RPPC. Q: quartzo; C-S-H: tobermorita; $\mathrm{C}$ : calcita; $\mathrm{Ca}(\mathrm{OH})_{2}$ : portlandita; $\mathrm{MgO}$ : periclásio; $\mathrm{H}$ : hemicarbonato; $\mathrm{C}_{2} \mathrm{~S}$ : belita; A: aragonita.] 
Table VI - Structural information of control and 12\% CFPW paste phases.

[Tabela VI - Informações estruturais das fases das pastas de controle e $12 \%$ RPPC.]

\begin{tabular}{ccc}
\hline $2 \theta$ & d-spacing $(\AA)$ & Phase \\
\hline $33.8^{\circ}$ & Control paste \\
$28.9^{\circ}$ & 3.32 & Quartz \\
$29.6^{\circ}$ & 3.09 & C-S-H \\
$34.3^{\circ}$ & 14.81 & Calcite \\
$39.7^{\circ}$ & 17.16 & Portlandite \\
$43.0^{\circ}$ & 19.85 & Calcite \\
& 21.49 & Periclase \\
$29.5^{\circ}$ & $12 \%$ CFPW paste & \\
$31.1^{\circ}$ & 3.03 & Calcite \\
$32.3^{\circ}$ & 2.88 & Hemicarbonate \\
$36.0^{\circ}$ & 2.77 & Belite \\
$39.5^{\circ}$ & 2.49 & Aragonite \\
$47.6^{\circ}$ & 2.28 & Calcite \\
$48.6^{\circ}$ & 1.91 & Calcite \\
\hline
\end{tabular}

Table VII - Compressive strength results of control mortar and mortar containing $12 \%$ CFPW addition.

[Tabela VII - Resultados de resistência à compressão de argamassas de controle e com adição de $12 \%$ de RPPC.]

\begin{tabular}{ccc}
\hline Mortar & $\begin{array}{c}\text { Compressive } \\
\text { strength (MPa) }\end{array}$ & $\begin{array}{c}\text { Relative standard } \\
\text { deviation }\end{array}$ \\
\hline Control & 32.2 & $5.3 \%$ \\
$12 \%$ CFPW & 34.0 & $4.2 \%$ \\
\hline
\end{tabular}

obtained for paste with $12 \%$ of CFPW addition was similar to the CFPW powder pattern showed in Fig. 1b. However, the peaks belonging to calcite became stronger, and hemicarbonate peak became weaker. The calcite addition in the cementitious matrix changed the hydrate cement products, as it induced the carboaluminate phase formation, as hemicarbonate [29]. Therefore, hemicarbonate, which is an unstable phase in the presence of high calcite amount, gradually converted into monocarbonate with hydration progress. Considering that the pastes were analyzed after 28 days of curing, the hemicarbonate phase decrease was expected. Clinker component (belite) was also observed at $32.3^{\circ}(2 \theta)$ on the XRD pattern of the paste with $12 \%$ of CFPW, implying in the presence of anhydrite cement phases in the paste. Among the major phases present in Portland cement, belite has the lowest reaction rate. Therefore, after 28 days of curing, just a small fraction of $\mathrm{C}_{2} \mathrm{~S}$ reacted [9]. The high overlap of data in the XRD pattern of the control paste indicated a high concentration of amorphous materials and a multiplicity of phases in the sample. This characteristic pattern turned phase identification and structural refinements more complicated, leading to misinterpretations.

Table VII presents the compressive strength results of control mortar and mortar containing 12\% CFPW addition. The major concentration of calcium carbonate phases in the $12 \%$ CFPW paste observed on diffractogram pattern justified the better compressive strength of $12 \% \mathrm{CFPW}$ mortar, as vaterite and calcite contributed to pore closure. These polymorphs present higher volumes than cement hydration products, which promote a filler effect on the cement matrix, reducing permeability, and increasing mechanical performance $[23,30]$.

Fig. 3 shows Rietveld refinement of the XRD pattern of the paste with $12 \%$ of CFPW addition. The excellent fit between the observed and calculated profiles reflected a value of $\chi^{2}=2.2$. The refinement indicated that the calcite (rhombohedral), vaterite, and portlandite phases were the majority with $52 \%, 27 \%$, and $7 \%$, respectively, in relation to the other phases mentioned in Table IV with percentages below 4\%. The crystallographic information file obtained in GSAS after the refinement was used to create a structure image with the Diamond software (Fig. $3 b)$. Considering that the CFPW addition contributed to crystalline phase formation and that the calcium polymorph presence enhanced matrix packing, the aragonite and calcite structure phases were chosen for analysis from Diamond

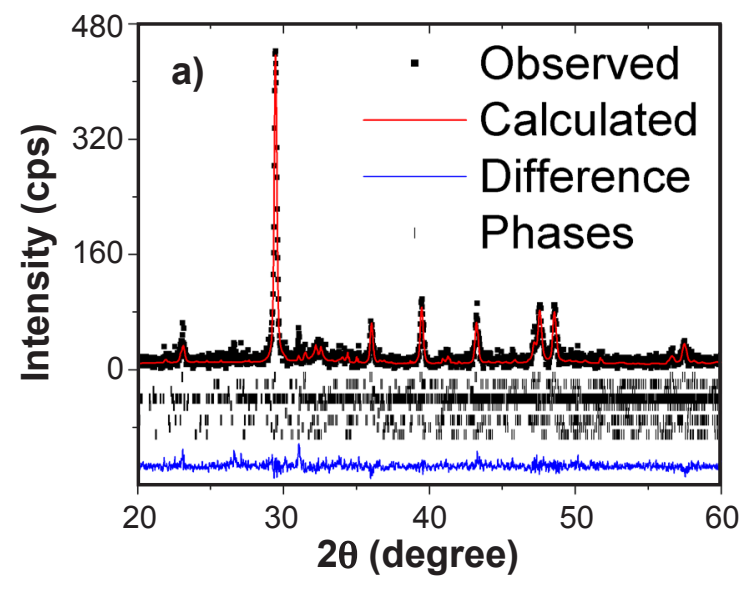

b)

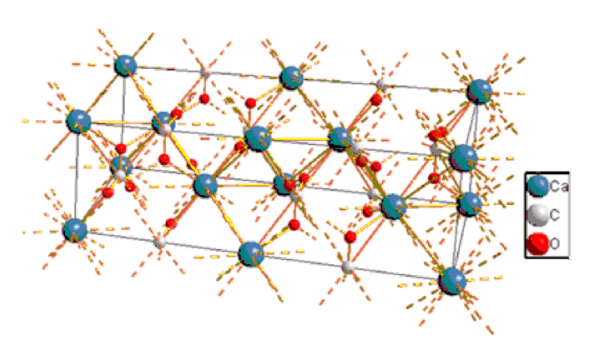

Figure 3: Rietveld refinement of XRD pattern of $12 \%$ CFPW paste (a), and calcite structure (b).

[Figura 3: Refinamento Rietveld do padrão de DRX da pasta de $12 \%$ RPPC (a) e estrutura da calcita (b).] 
software information. The reinsertion of this material into the productive cycle represents an important alternative for sustainable development. Considering the importance of finding solutions for waste use produced in different economic sectors, this work has so far presented the structural characteristics of concrete floor polishing residue in the cement matrix. Experiments are being carried out to understand the mechanical and microstructural properties to infer about this material applicability in civil construction.

\section{CONCLUSIONS}

Structural properties of a cement paste incorporating concrete floor polishing waste (CFPW) were studied. X-ray diffraction (XRD) pattern of CFPW indicated the presence of calcium carbonate polymorphs and hemicarbonate. This indicated that the concrete hydrate components were carbonated, which favored the carboaluminate phase formation when added to the cementitious matrix. The XRD technique proved to be feasible to study cement anhydrous and hydrated phases since it allows the phase formation identification. Rietveld refinement showed that the calcite, vaterite, and portlandite phases were the majority in the CFPW.

\section{ACKNOWLEDGMENTS}

The authors would like to acknowledge Universidade Estadual Paulista (UNESP, campus Ilha Solteira), Universidade de Rio Verde (UniRV), and Instituto Federal Goiano for all facilities offered.

\section{REFERENCES}

[1] T. Hemalatha, M. Gunavadhi, B. Bhuvaneshwari, S. Sasmal, N.R. Iyer, Cem. Concr. Compos. 58 (2015) 114.

[2] M. Rupasinghe, R.S. Nicolas, P. Mendis, M. Sofi, T. Ngo, Cem. Concr. Compos. 80 (2017) 17.

[3] C. Zhu, Y. Fang, H. Wei. Constr. Build. Mater. 192 (2018) 224.

[4] K. Scrivener, R. Snellings, B. Lothenbach (Eds.), “A practical guide to microstructural analysis of cementitious materials", CRC Press, Florida (2017).

[5] P.K. Mehta, P.J.M. Monteiro, Concreto: microestrutura, propriedades e materiais, Ibracom, $2^{\text {nd }}$ ed., S. Paulo (2014). [6] H.M. Ludwig, W. Zhang, Cem. Concr. Compos. 78, Part A (2015) 24.
[7] S. Maheswaran, S. Kalaiselvam, S.K.S.S. Karthikeyan, C. Kokila, G.S. Palani, Cem. Concr. Compos. 66 (2016) 57. [8] L. Gobbo, L. Sant'Agostino, L. Garcez, Cem. Concr. Compos. 34 (2004) 657.

[9] P. Hewlett, Lea's chemistry of cement and concrete, Butterworth-Heinemann, $4^{\text {th }}$ ed., Oxford (2003).

[10] B. Lu, C. Shi, J. Zhang, J. Wang, Constr. Build. Mater. 186 (2018) 699.

[11] G.L. Saoût, V. Kocaba, K. Scrivener, Cem. Concr. Compos. 41 (2011) 133.

[12] R. Snellings, A. Bazzoni, K. Scrivener, Cem. Concr. Compos. 59 (2014) 139.

[13] G.A. Calligaris, M.K.K.D. Franco, L.P. Aldrige, M.S. Rodrigues, A.L. Beraldo, F. Yokaichiya, X. Turrillas, L.P. Cardoso, Constr. Build. Mater. 98, 15 (2015) 44.

[14] Z. Chen, C.S. Poon, Constr. Build. Mater. 154, 15 (2017) 791.

[15] ABRELPE, "Panorama dos resíduos sólidos no Brasil 2017" (2018) http://abrelpe.org.br.

[16] ASTM C150/C150M, "Standard test method for Portland cement”, ASTM, Pennsylvania (2018).

[17] B.H. Toby, J. Appl. Cryst. 34 (2001) 210.

[18] P. Thompson, D.E. Cox, J.B. Hastings, J. Appl. Crystallogr. 20 (1987) 79.

[19] L.B. McCusker, R.B. Von Dreele, D.E. Cox, D. Louërd, P. Scardi, J. Appl. Crystallogr. 32 (1999) 36.

[20] H. Zhou, X. Gu, J. Sun, Z. Yu, H. Huang, Q. Wang, X. Shen, Constr. Build. Mater. 182, 10 (2018) 156.

[21] M. Courtial, M.-N. de Noirfontaine, F. Dunstetter, G. Gasecki, M. Signes-Frehel, Powder Diffr. 18, 1 (2003) 7.

[22] I. Maki, K. Kato, Cem. Concr. Res. 12, 1 (1982) 93.

[23] T. Staněka, P. Sulovský, Cem. Concr. Res. 32, 7 (2002) 1169.

[24] M. Arandigoyen, B. Bicer-Simsir, J.I. Alvarez, D.A. Lange, Appl. Surf. Sci. 252, 20 (2006) 7562.

[25] B. Šavija, M. Luković, Constr. Build. Mater. 117, 1 (2016) 285.

[26] H. Choi, M. Inoue, R. Sengoku, Constr. Build. Mater. 188, 10 (2018) 1.

[27] Y. Yue, J.J. Wang, P.A.M. Basheer, J.J. Boland, Y. Bai, Constr. Build. Mater. 135, 15 (2017) 369.

[28] M. Zajac, A. Rossberg, G.L. Saout, B. Lothenbach, Cem. Concr. Compos. 46 (2014) 99.

[29] A. Ipavec, R. Gabrovšek, T. Vuk, V. Kaučič, J. Maček, A. Meden, J. Am. Ceram. Soc. 94, 4 (2011) 1238.

[30] W. Ashraf, Constr. Build. Mater. 120, 558 (2016) 570.

(Rec. 20/06/2019, Rev. 25/09/2019, 08/03/2020,06/05/2020, Ac. 11/05/2020)

(CC) BY-NC 